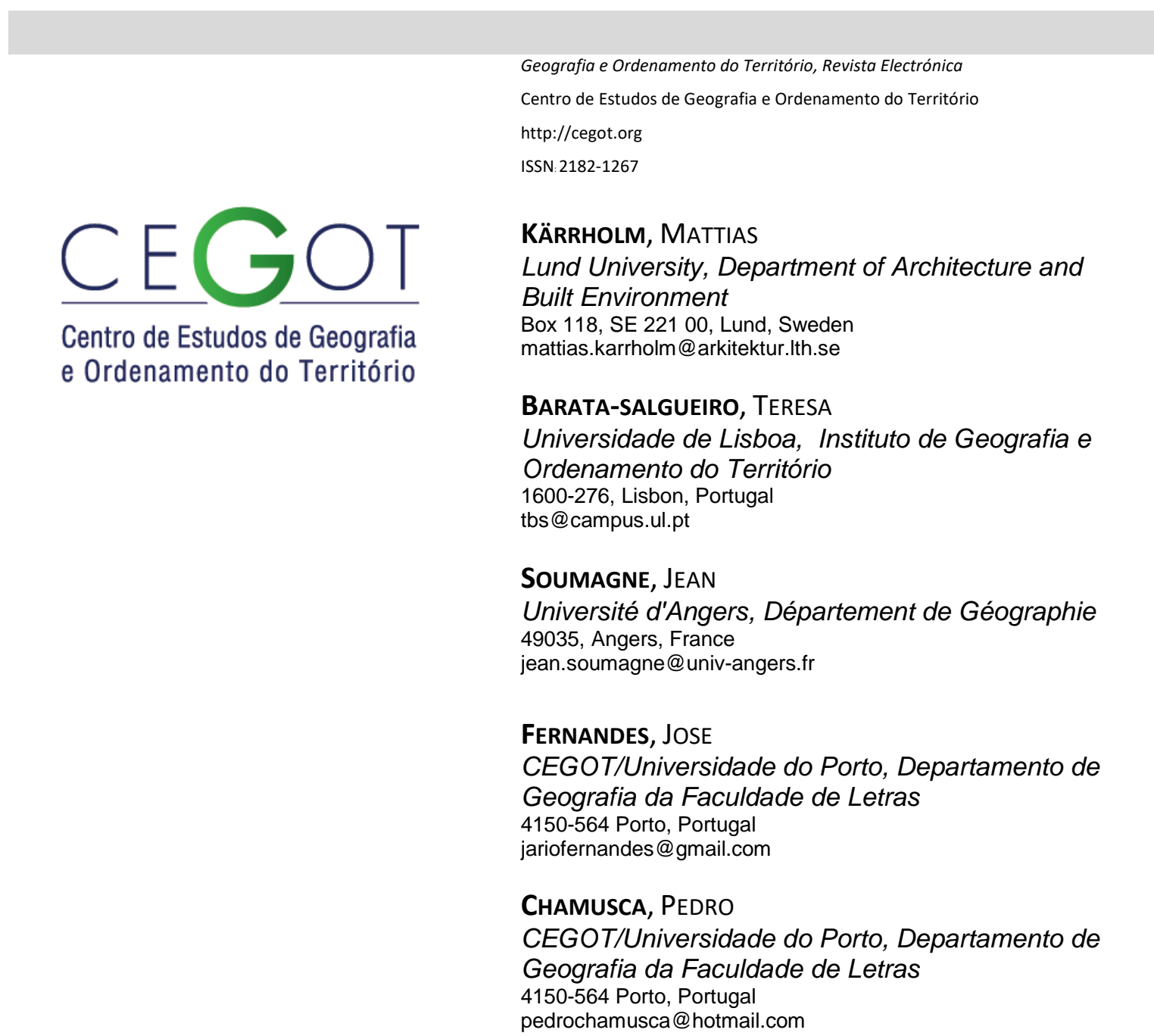

\title{
Time-space complexity and the opening hours of commerce: a study of four European cities
}

Complexidade tempo-espaço e os horários dos estabelecimentos comerciais: um estudo em quatro cidades europeias

Referência: Kärrholm, Mattias et. al (2017). Time-space complexity and the opening hours of commerce: a study of four European cities Revista de Geografia e Ordenamento do Território (GOT), n.o 12 (dezembro). Centro de Estudos de Geografia e Ordenamento do Território, p. 153-177, dx.doi.org/10.17127/got/2017.12.007

\section{ABSTRACT}

The aim of this article is to develop the concept of time-space complexity as a way of discussing how territorial time-space production affects urban life and use. The discussion is based on a comparative study of opening hours in four centrally located European retail areas: Angers, Lisbon, Malmö and Porto. Following a comparative study of these areas, we discuss tendencies of temporal and spatial homogenisation, the production of ever-more 
distinctive time-spaces, and also initiate a discussion on the trend of city a la carte. Finally we argue that discussions of time-space complexity need to be taken more seriously in research on urban development, and that the issue of spatio-temporal homogenisation need to be handled more actively in urban planning and design.

Keywords: Consumption, urban planning, opening hours, city centres, public space, timespace

\section{RESUMO}

O objetivo deste artigo é desenvolver o conceito de complexidade tempo-espaço com o objetivo de discutir de que forma a produção territorial temporal e especial influencia a vida urbana e a utilização da cidade. A análise baseia-se num estudo comparative dos horários de abertura dos estabelecimentos comerciais em quatro áreas comerciais europeias localizadas em espaços centrais: Angers, Lisboa, Malmö e Porto. Com base no estudo comparative destas áreas, discutimos as tendências de homogeneixação temporal eespacial, a produçao de tempos e espaços ainda mais distintivos, e iniciamos ainda a discussão sobre a tendência de uma city á la carte. Por fim, defendemos que o debate sobre a complexidade tempo-espaço deve ser considerada de forma mais efetiva na investigação sobre desenvolvimento urbano e que o tema da homogeneização temporal e especial deve ser integrado ativamente no planeamento e desenho urbano.

Palavras-chave: Consumo, planeamento urbano, horários de abertura, centros de cidade, espaço público, tempo-espaço

Western societies have shifted from an industrial society marked by synchronised urban rhythms to a much more heterogeneous consumer society in which people's lives follow more individual agendas (Lynch 1972; Shove et al., 2009). Non-regulated working hours, increased personal mobility, longer life expectancy and more time for leisure are some of the changes that have positioned time higher up on the research agenda. The transformations of time-use and time constraints have prompted numerous planning initiatives in Europe, notably the Urban Time Plans of Italy, which began in the early 1990s with the Urban Time Plan of Milano. In 2000, with the Turco Act, Urban Time Plans became compulsory for all Italian cities with more than 20000 inhabitants (Belloni, 1998; Mareggi, 2002). Other time planning initiatives include, for example, the opening of so-called Time Offices in some French cities (Delfour and Dommergues, 2003), and a wide range of different initiatives in countries such as Germany, Ireland, the Netherlands and Finland. The urgent need to address time-issues has also been acknowledged by the Congress of Local and Regional Authorities of the Council of Europe, which adopted a recommendation and a 
resolution in 2010 regarding the use of time policies and the right to one's own time (Mückenberger, 2011). Parallel to this development, aspects of time and time-space have also come to the fore in the social sciences in general, and perhaps in urban planning (van Schaick 2011; Henckel et. al. 2013; Mulícek et al., 2015) and human geography in particular (May \& Thrift 2001; Crang 2001; Edensor, 2010; Merriman, 2011; Bishop \& Williams, 2012).

As the temporal complexities of everyday life seem to be increasing, the rise of consumer society has also brought about the territorialisation of large-scale areas or city districts for one principal function - retail, campus, residential or office areas, for example. The isorhythmic evolution (cf. Lefebvre, 2004; 2009) brought by modernist zoning and planning thus continues, but this time by other means, such as theming and branding (Graham \& Marvin, 2001; Klingmann, 2007). Although people tend to lead more mobile lives and work non-regulated hours (Delfour and Dommergues, 2003), some urban areas seem to be evolving on an increasingly large scale, and with diminished temporal complexity, thus leaving large urban areas devoid of activity for extended periods of the day or week. This kind of urban development goes hand in hand with the homogenisation of both time and space, and thus seems to contradict the increasingly diverse and complex needs of everyday life.

There is a lot of research that, one way or another, focuses on the spatio-temporal homogenisation of cities. There are, for example, studies on the problems of fragmentarisation (Barata Salgueiro 1997; Graham \& Marvin, 2001), domestication (Atkinson 2003), synchronisation (Kärrholm 2009), and privatisation (Low 2006), just to mention a few. However, what is perhaps less common are studies that not just discuss homogenisation as a phenomenon of black and white (or less and more), but as a more layered structural problem. In this article, we aim to develop such a perspective through the notion of territorial time-space complexity; in short this implies a discussion that addresses how the territorial structures of different public spaces might vary. Territorial claims all have their different spatial extensions and different durations, and they might thus overlap or be mutually exclusive with other territorial claims of the same place, i.e. each place tends to have its own structure of territorial claims, where processes of homogenisation and heterogenisation can go on simultaneously (Kärrholm 2007). 
In order to discuss the issue of time-space complexity we will here take opening hours as an example, and discuss their structural effects on urban life and use. Time-space complexity is, of course, not just produced by retail services but by a series of claims made by all the different actors, groups, institutions, rites, regulations, etc. of a specific place. However, even a perhaps simple yet pervasive, phenomenon such as opening hours can have deep effects on the territorial structure of a place or a city. Opening hours are examples of a strategic commercial time-space production, and set an important background rhythm to many urban districts. Retail has also been considered important for the study of urban rhythms (Cronin 2006; Warnaby 2013), where retail synchronization to some extent can influence the whole of an urban landscape (Kärrholm 2009:436). This is mainly because these activities function as pacemakers (Parkes \& Thrift, 1980; Mulícek et al., 2015) for public life as they set a rhythm and attract people during certain hours. This is especially true in city centers and busy retail areas. ${ }^{1}$

In the first part of the article we will introduce and discuss the notion of time-space complexity. In the second, we compare opening hours and the rhythms of urban life in four different centrally located European retail areas: the pedestrianised city centres of Angers (France) and Malmö (Sweden), and the two centrally located and semi-pedestrianised areas of Chiado in Lisbon and Aliados in Porto (Portugal). In the third part of the article we discuss how the structure of these opening hours during a week might have effects on the timespace complexity of the areas. In the fourth and final part before the conclusion, we then discuss how the change in time-space complexity brought by a standardisation of opening hours might contribute to a development of what has been called a City à la carte.

\section{Studying time-space complexity}

As urban time polices are being increasingly implemented all over Europe, it is becoming important to develop a times-of-the-city, or chronotopic approach, in order to investigate

\footnotetext{
${ }^{1}$ Paiva et al. (2017) has, for example, showed in their study of a residential suburb, that public life here is less synchronized with retail, and that retail use instead is influenced by the temporalities of public life.
} 
and map the changing temporal morphology of urban space (cf. Mareggi, 2013:7). In recent years we have witnessed an increase in research using rhythmanalysis, (Edensor, 2010; Mareggi, 2013; Wunderlich 2013; 2014), time-lapse studies (Simpson, 2012), and other spatio-temporal methods (Neuhaus, 2011). On a more theoretical level, time-space perspective has been advocated by, for example, by Schatzki (2010). The ontological status of time-space has, however, also been questioned by Peter Merriman (2011). In this article, we recognise that space and time are interwoven (Massey, 1994). Time-space is here not regarded as an ontological a priori, but as something produced through use. In the following, we are especially interested in time-space as territorially produced. Territoriology has recently been developed as a research area that does not focus on territory as an object, but rather on territoriality as a set of expressive and boundary-producing power relations (Brighenti, 2010; 2014). Territories are the results of these power relations. One advantage of defining territory as an act or event is the possibility of opening a more elaborate discussion on a temporal perspective of territoriality. Just as territory "defines space through patterns of relations" (Brighenti, 2010:57), it should be acknowledged that territories also define times and temporalities (Brighenti and Kärrholm 2016; Kärrholm 2017). Territorial production is, in short, expressive and bounded (although these boundaries might sometimes be blurred and hard to identify) entities of a certain extension in time and space.

In this article, we use the concept of time-space complexity in order to initiate a discussion of how the territorial production of time-space through retail and services affects the use of some centrally located urban areas. Each public space is made up of different territorial production. Some territories are strategically planned and managed such as parking lots, market squares, pedestrian streets, individual stores, etc. Some territories are temporarily claimed by groups, such as tourist, shoppers, youths, etc. Others can be produced by means of association or atmospheres such as a "perfect spot for waiting" or a "monumental square". Usually, living public spaces are produced as effects of different overlapping territorial productions, forming territorial complexities (Kärrholm 2007). So how can we describe these territorial complexities? In order to highlight that territorial production is as much about temporal as spatial demarcation, we will refer to them as territorial time-space complexities. In this case, time-space complexity refers to a territorial production of 
temporal uses and meanings in public space that to some extent co-operate and overlap, without one specific production dominating the others. A complexity in this regard is characterised through three points (cf. Kärrholm 2007: 446-48; Law and Mol's description of complexities, 2002):

1. They include a large number of different territorial productions

2. Territorial productions overlap

3. There is a non-hierarchical relationship between the different territories.

Territorial production includes the formal or informal claiming of time-space, producing a certain observable spatio-temporal effect. In an urban setting, such territorial productions (and reproductions) could include anything from a retail store that has been in activity for generations, to the temporal claiming of a bench by a person drinking coffee.

If we compare an urban square with a shopping mall, the square would often (but not necessarily always) be regarded as more complex. A square is usually the stage for several different kinds of territorial productions during a week: there may be cars parking, people biking, perhaps a small market, a street musician, stores situated on the square's perimeters, outdoor restaurant seating, etc. These productions often overlap spatially, so that one day's marketplace might be replaced by a political gathering the next. Furthermore, the territorial productions of the square are seldom subject to rigid vertical organisation: there is no 'master of the place' ruling the sub-territories as in the case of a shopping mall. Instead, there are different variables, and rules are managed from different governing organs and/or more or less autonomous bodies. The central location of the areas investigated in this article means that a certain degree of time-space complexity involving territorial productions and various uses could be anticipated. In the following however, we will not map the full scope of this complexity, but rather focus on retail in order to subsequently elaborate on how the retail of these areas might affect the area - and perhaps even the urban landscape - as a whole. The temporal landscape of the city is associated with variables of different sorts, shapes and sizes. Opening hours, which will be the focus of this text, are of course just one type of avariabler, and it is important to be aware of timespace as something produced by a heterogeneity of different human and non-human 
variables or actors (Latour, 2005), ranging from large-scale infrastructures down to the use of artefacts.

\section{Opening hours of commerce}

In order to study time-space complexity we have taken the easy accessible case of opening hours of commerce, with examples from four different cities in Europe: Angers, Lisbon, Malmö and Porto. Retail opening hours have increasingly been deregulated in Europe during the last decades. This can be associated with secularisation, new consumer demands and a weaker protection of employees. Retail opening hours are not heavy regulated in the countries investigated in this study. In Portugal opening hours are regulated from 6.00 to 24.00, but with exception of, for example, convenience stores, bars, petrol stations and airport terminals. In Sweden retail opening hours are fully deregulated, and have been so formally since 1972. In France opening hours are unrestricted, except for Sundays, although indirectly this is not always the case, due to labour legislation (Soumagne 2015). On Sundays most shops are closed with the exception of e.g. food shops, furniture stores, garden centres and some other cases (See Boulin 2013, for a discussion on Sundays). There are also some local rules and exceptions - tourist areas are, for example, often unrestricted (cf. Boylaud and Nicoletti 2002: 263).

Despite a quite unregulated situation, we can spot some notable differences in terms of opening hours and time-space accessibility between the three countries. The aim of the comparison is, as mentioned, to initiate a discussion on the impact of commercial timespace production and we do thus not seek to generalise the empirical findings to other cities, although they all share several contemporary challenges with other European retail districts. The cities are median size European cities with a commercial core with regional attraction, and even national attraction in case of Lisbon. They all face the challenges associated with the development of new out-of-town retail formats, like hypermarkets, shopping centers and other retail centers. The city centers have registered changes in the last decades, firstly decline of the main functions along with decay of the buildings, and then 
recovering (regeneration) partly associated with increasing tourism, new lifestyles and gentrification. Finally, and most importantly, there are also practical reasons: since 2009 we have been studying these cities under two European projects. Besides each researcher's knowledge about his/her own city, we, as a group, had accumulated an important amount of information through the data gathered, our discussions and our findings.

The areas selected are relatively similar in terms of the distribution of services and retail (see table 1). Food stores are uncommon, as they are in many European city centres (cf. Wrigley, 2002), whereas restaurants and cafes are becoming more common in relation with the increase of city-users. A high proportion of the retail establishments focus on personal goods such as apparel and fashion accessories. The number of restaurants and cafés seems to be increasing in all of the four districts, but the increase is most perceptible in Malmö where, for example, the Main Square of the city has almost doubled its restaurants in the last thirty years, and where the adjacent square, formerly housing a market hall has developed into a kind of open air food court, totally dominated by restaurants and bars. Porto is also a case of increased "cappuccino culture", with the city centre number of coffee shops and restaurants increasing 16,7\% in just the last 3 years, going from 78 in 2012 to 84 in 2014 (Fernandes \& Chamusca, 2014) and 91 in 2015.

The study of opening hours is based on a series of synchronised empirical studies made in the four areas in November of 2012 and it includes the mapping of stores and services, comprising a total of almost 1000 facilities in the four cities and of opening hours for these stores (table. 1), as well as time-lapse studies of every street in the area, taken every hour for three days, in order to gather information on fluctuating pedestrian flows at different points during the day and week. The studies were made between 8.00 and 22.00 on each day. The weather conditions in the cities were normal for the season and ranged between sunny and cloudy with some wind (but no storms or rain). 


\begin{tabular}{|l|l|l|l|l|l|l|}
\hline $\begin{array}{l}\text { Stores and } \\
\text { services }\end{array}$ & $\begin{array}{l}\text { City centre- } \\
\text { Angers }\end{array}$ & $\begin{array}{l}\text { Aliados- } \\
\text { Porto }\end{array}$ & $\begin{array}{l}\text { City centre- } \\
\text { Malmö }\end{array}$ & $\begin{array}{l}\text { Chiado- } \\
\text { Lisbon }\end{array}$ & $\begin{array}{l}\text { Mean } \\
\text { value }\end{array}$ & $\begin{array}{l}\text { Category } \\
\text { totals }\end{array}$ \\
\hline Food and delicacy & $6 \%(17)$ & $5 \%(13)$ & $4 \%(5)$ & $4 \%(8)$ & $5 \%$ & 43 \\
\hline $\begin{array}{l}\text { Personal goods, } \\
\text { household and } \\
\text { home }\end{array}$ & $53 \%(165)$ & $38 \%(110)$ & $48 \%(60)$ & $53 \%(116)$ & $49 \%$ & 455 \\
\hline $\begin{array}{l}\text { Culture and } \\
\text { leisure }\end{array}$ & $14 \%(42)$ & $19 \%(54)$ & $11 \%(13)$ & $18 \%(39)$ & $16 \%$ & 148 \\
\hline $\begin{array}{l}\text { Restaurants and } \\
\text { cafés }\end{array}$ & $22 \%(68)$ & $26 \%(74)$ & $29 \%(36)$ & $20 \%(44)$ & $24 \%$ & 222 \\
\hline $\begin{array}{l}\text { Hotels and } \\
\text { hostels }\end{array}$ & $0 \%(1)$ & $6 \%(18)$ & $3 \%(4)$ & $2 \%(5)$ & $3 \%$ & 28 \\
\hline Financial services & $5 \%(16)$ & $6 \%(18)$ & $5 \%(6)$ & $3 \%(6)$ & $5 \%$ & 46 \\
\hline Total & $100 \%(309)$ & $100 \%(287)$ & $100 \%(124)$ & $100 \%(218)$ & $100 \%$ & 938 \\
\hline
\end{tabular}

Table 1. Stores and services.

\subsection{Angers Centre}

Angers is a mid-sized town in Loire with a centre surrounded by suburban areas (in 2011, the municipality: 148 800; with suburbs: 227 000; and the metropolitan area: 400 000). The heart of urban and commercial life is the Place $d u$ Ralliement, dating back from the late $18^{\text {th }}$ century but remodelled many times since. The square is surrounded by cafés and restaurants, and also includes a department store, a theatre and a tram station. The square is also the centre of the intersecting network of pedestrian streets that constitute the city's commercial core. In Angers (fig. 1), most shops open between 9.00 and 10.00 on weekdays and close between 18.00 and 19.00. Opening hours are almost identical on Saturdays; however, as in many other French cities, a very high proportion of shops and services are closed on Sundays in Angers. The small minority of establishments with Sunday opening hours includes essentially only two categories: restaurants/cafés and food stores. 


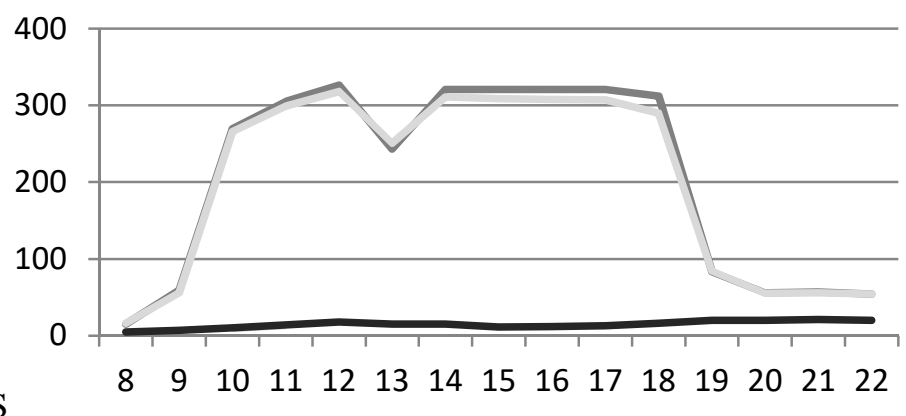

ANGERS

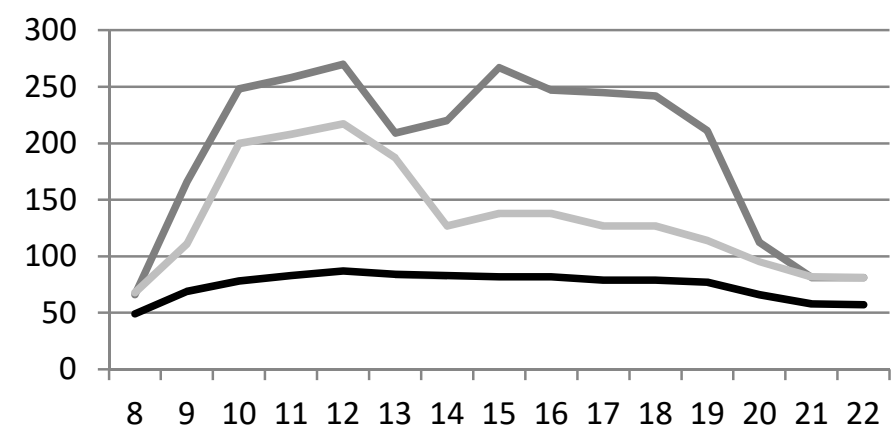

PORTO

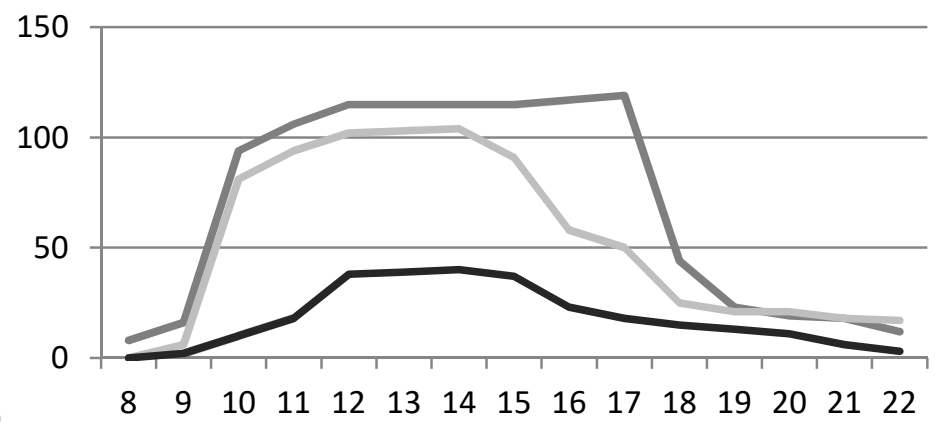

MALMÖ

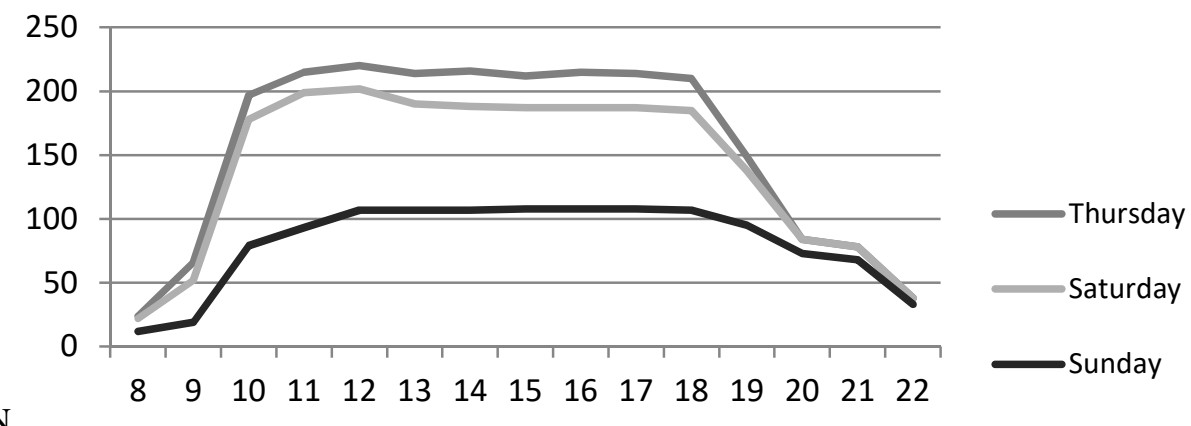

LISBON

Fig 1. Number of open stores/services at a certain hour.

The historic centres of most French cities appear to be shifting towards continuous opening hours with no midday closure, as well as opening hours that extend into the evening, 
particularly on Fridays and Saturdays, but shops that close around lunch time are by no means uncommon. Commercial schedules have started to change due to the specialisation of some sections of streets and squares: the stronger the presence of restaurants and chain stores, the more likely it is that opening hours will extend and become continuous. Official regulations hinder shops that sell personal or cultural goods from remaining open past 19.00, with the exception of during specific sale periods. The three pedestrian streets (Lenepveu, Alsace and Saint-Aubin) have standard hours with Sunday closing, and they thus appear quite empty on Sundays.

\subsection{Aliados, Porto}

The municipality of Porto, with 238000 inhabitants (in 2011), is the core of a metropolitan area of 1.8 million inhabitants composed of 17 municipalities. Aliados Avenue is centrally located in Porto, just north of the historic centre, and was opened in 1916 as an extension of the central square, Praça da Liberdade. The avenue has a monumental architecture (including the Town Hall), and can be seen as a contrast to the older and more densely built old city. It has wide sidewalks and a central pedestrianised plateau, and it is located adjacent to other pedestrianised areas of the city centre, although it is easily accessible by car. Despite a decreasing number of residents, Porto's symbolic value is very significant, and the city is growing in popularity as a leisure destination for the suburban population, and especially as a destination for tourists and also for students. In fact, the city's increasing popularity - which was amplified by UNESCO's classification as a world heritage site - can help explain why the municipality of Porto recorded a growth of $48.6 \%$ in its accommodation capacity between 2004 and 2010, and why the city centre has become fashionable once again (Fernandes, 2011). Aliados has remained a privileged space for events, visits and nocturnal activities and the gathering space of spontaneous manifestations, associated with politics or football, or the site of several events promoted by the municipality and a variety of other organisations, in diverse domains such as art, gastronomy and entertainment (Fernandes et al, 2013).

In Porto, opening hours differ somewhat from Angers. First of all, shops are open longer. Most shops open at 9.00 (rather than 10.00, as is the case in Angers) and close at 19.00 
(rather than 18.00), and a greater number of businesses - mostly restaurants and cafés are open on Sundays. In addition, about $20 \%$ of the shops close for lunch. The traditional model of the industrial city, in which the city centre is abandoned on weekends and after 21.00, has changed dramatically in the context of professional flexibility and public deregulation, compatible with the diminishing number of residents and the increased relevance of city users. As a consequence, "the nightlife of Baixa" has consolidated over the last decade and it has become usual to see people on the streets in and around Aliados from sunset to sunrise.

\subsection{Malmö Centre}

Malmö is Sweden's third largest city (municipality: approx. 310000 inhabitants in 2014), located a mere half an hour by train from Copenhagen, Denmark. Malmö larger metropolitan area (on the Swedish side) includes twelve municipalities and 682000 inhabitants, and with Copenhagen it forms part of the larger Öresund Region of 3.8 million people (2012). The majority of shops in Malmö open at 10.00 and close between 18.00 and 19.00 on weekdays. During the week, it bears more resemblance to Angers - though without the midday closing - and on Saturdays it has more of a likeness to Porto, although stores tend to close earlier: around 14.00 or 15.00 . Only a few stores are open on Sundays, and these are mostly larger stores, or chain stores. Sunday opening hours are more generous than in Angers, and if we compare with Porto, they involve a larger ratio of stores; i.e. it is not limited to cafés and restaurants). In Sweden, retail underwent a series of rationalization processes in the second half of the $20^{\text {th }}$ century, which resulted among other things in larger stores: the number of shops larger than 400 square meters has risen from 0\% in 1950 to $75 \%$ of the market during the mid-90s (Kärrholm and Nylund 2011). Natural rhythms constituted by lunch breaks (for shop owners and staff) or cultural rhythms of, for example, calm Sundays, are becoming less important in a lot of European cities, and also in Sweden. Opening hours were as mentioned already deregulated in Sweden in the early 1970s, but the large-scale effects were not felt before the 1990s and thereafter. 


\subsection{Chiado, Lisbon}

Lisbon is the core of a metropolitan area of 18 municipalities with 2.8 million inhabitants (in 2011). It is also part of the Atlantic Megalopolis, which stretches from the Lisbon region to La Coruna (Spain). The central municipality (Lisbon) has 545000 inhabitants, but it has been losing residents to the outskirts since the 1980s with the rise of a more polycentric metropolitan structure. The Lisbon city centre is the centre for occasional consumption practices of the metropolis, and the main users of the area include residents in the inner city districts (mostly elderly people with low incomes), local workers, consumers coming from outside the city, and tourists. Lisbon city centre comprises two main but diverse subareas: Baixa and Chiado. Chiado is both the name of a small square and the neighbourhood that lies on a hill west of Baixa, also partly rebuilt in the 18th and 19th centuries (after the Lisbon earthquake). Chiado is mainly an exclusive retail and office area. After a period of disrepair and decay during the 1970 s to the 1990s, intensified by the great fire in 1986, Chiado became a dynamic retail district and a vibrant social and cosmopolitan area. A gentrification process (both functional and residential) is still underway and pushing rents upwards. Retail is dominated by personal goods such as clothing and fashion, footwear and accessories, but includes a large variety of retail categories. The area is partly pedestrianised and the ratio of chain stores is high, and these are mainly concentrated in Carmo and Garret Streets (see fig. 2), along with the upper part of Rua Nova do Almada. At their intersection is the anchor and shopping centre Armazéns do Chiado, which became an important motor for retail regeneration of the whole area when it opened in 1999. Important attractions in the area also include the Opera House, theatres and cultural institutions such as the Faculty of Fine Arts and the Carmo Monastery ruins. The number of hotels and hostels is also rising. Traditionally, Chiado's shops were closed on Sundays and at midday, but they now open at 9.00 or 10.00 and close between 19.00 and 20.00. Stores in the shopping centre close later, around $22.00-23.00$. Cafés open earlier (7.30 or 8.00$)$ and close at 22.00 , and restaurants and bars generally have longer opening hours. Saturdays do not differ significantly from weekdays, and approximately half of the shops are open on Sundays. Small retailers close their stores earlier (around 19.00) while medium-sized retailers and global brands close later (around 20.00 or 21.00 ), and open seven days a week. Certain types of retail and services, such as restaurants or hotels, have no weekly variations. Thus, the shops that remain open 
on Sundays are predominantly superstores, franchised outlets or chain stores and the shops located within the shopping centre. Most of the shops that are closed on Sundays are small, independent firms with few employees or family businesses.

\section{Time-space complexity in central retail districts}

There are, of course, cultural differences in time-use. Swedish meals are often taken at least an hour earlier than Portuguese. In France, mealtimes are more important than in a lot of other European countries; more time is spent eating, and meals are more clearly focused around the periods from 12.00-14.00 and 19.00-21.00 (see also Shove, 2009: 21-24). In some cities, such as Porto and Angers, some stores close for lunch, in Malmö not a single store of the investigated area took a lunch break. However, some developments seem also to be crossing national borders. All of the four investigated areas exhibit similar tendencies of change in terms of opening hours, albeit to varying degrees: there is a steady elongation into evenings and weekends, as well as a shift towards more continuous opening hours; i.e. without midday closure. The role of work in local inhabitants' lives seems to have decreased, whilst leisure time and the role of tourists seem to have increased. However, the observed pedestrian density increases at midday when office staff has their lunch break. Food stores have moved out of many European city centres, and they make up no more than about $5 \%$ of the investigated services in our study, whilst restaurants, cafés and cultural events make up $24 \%$, and seem to be on the increase. Overall, the fall in the relative weight of the purchase of foodstuffs compared with cultural and leisure goods and those related to well-being and appearance (as well as services) to some extent also contributes to the attractiveness of central retail districts and peripheral shopping centers. City centres seem to have assumed a more important part in a growing consumption culture of experiences; i.e. a culture that sets the consumption of experiences and a territory as of greater importance than that of buying and owning goods. The extension of such a development might perhaps bring an increasing trend in timeshare properties or the leasing of goods (as noted by Bishop and William, 2012:68), or hopefully even a trend toward a 
'greener' peer-economy and new open-source strategies, but a development of this nature was not discernible based on our studies. The reasons for change towards consumption - of goods, services, experiences and places - as an increasingly important conductor of temporal use are numerous (Mareggi 2013, cf. Crang 2001; Miles and Miles 2004). They include the development of larger, polycentric metropolitan areas; the general rise of incomes (e.g. the increasing number of employed women, especially in Portugal) and mobility; the expansion of the consumption culture; greater flexibility that has brought greater diversity to working and shopping schedules; and the rise of tourism (cf. Balsas 2004). The increasing number of tourists and incoming consumers of culture and goods seems to compensate for the decreasing number of residents in inner city areas, perhaps most clearly in Lisbon, but certainly also in Malmö.

\begin{tabular}{|l|l|l|l|l|}
\hline & $\begin{array}{l}\text { Number of hours } \\
\text { open, per store } \\
\text { and day during a } \\
\text { week }\end{array}$ & $\begin{array}{l}\text { Number of hours } \\
\text { open, per store on } \\
\text { Weekdays }\end{array}$ & $\begin{array}{l}\text { Number of hours } \\
\text { open, per store on } \\
\text { Saturdays }\end{array}$ & $\begin{array}{l}\text { Number of hours } \\
\text { open, per store on } \\
\text { Sundays }\end{array}$ \\
\hline Malmö (Centre) & $7,2 \mathrm{~h}$ & $8,4 \mathrm{~h}$ & $6,4 \mathrm{~h}$ & $2,2 \mathrm{~h}$ \\
\hline Angers (Centre) & $8,2 \mathrm{~h}$ & $9,5 \mathrm{~h}$ & $9,3 \mathrm{~h}$ & $0,7 \mathrm{~h}$ \\
\hline Porto (Aliado) & $8,8 \mathrm{~h}$ & $10,2 \mathrm{~h}$ & $7,0 \mathrm{~h}$ & $3,9 \mathrm{~h}$ \\
\hline Lisbon (Chiado) & $9,9 \mathrm{~h}$ & $10,8 \mathrm{~h}$ & $9,7 \mathrm{~h}$ & $5,6 \mathrm{~h}$ \\
\hline $\begin{array}{l}\text { Armazens do Chiado } \\
\text { (Lisbon) }\end{array}$ & $8 \mathrm{~h}$ & $8 \mathrm{~h}$ & $9 \mathrm{~h}$ & $7 \mathrm{~h}$ \\
\hline Emporia (Malmö) & $12 \mathrm{~h}$ & $12 \mathrm{~h}$ & $12 \mathrm{~h}$ & $12 \mathrm{~h}$ \\
\hline
\end{tabular}

Table 2. Number of hours open per store and day under the investigated period

If we look at overall intensity of retail and services as given by opening hours, Chiado seems to be the most accessible and intensely retailised area (see table 2). In Chiado, the access to stores and services is fairly constant throughout the whole week, whilst the stores of Malmö, Porto and Angers tend to be closed on Sundays (although one might see a small increase in Sunday opening hours in Malmö and Porto). Sweden is often mentioned as the most deregulated European country in terms of retail opening hours, and the effect of this deregulation in terms of price decrease and increase in sales is well documented 
(Civildepartementet 1991, cf. Gradus 1996). Still, Malmö inner city is actually the area with the lowest mean number of opening hours. The opening hours of the four central retail areas with their two different shopping malls can be compared in table 2 (i.e. the Chiado statistics include Armazens do Chiado). The Emporia shopping mall, which opened in the outskirts of Malmö in October 2012, is open seven days a week from 10.00 and 22.00, giving an intensity of 12 open hours per store per day - the highest in the table. This can be compared with the 7.2 open hours daily per store in Malmö city centre - the lowest of the four city centres/districts.

In terms of a general time-space complexity, all areas show a relative large degree of heterogeneity, with actors such as tourists, students, guest workers, immigrants, people working irregular hours, etc. (although the relative number of different groups tends to vary). In addition, non-human actors including new store concepts and hybrid formats such as pop-up stores and in-store dining, as well as new gadgets and artefacts such as cell phones, backpacks, computers and skateboards, seem to have increased. There is, in all the areas, a mix, but it appears to be a themed mix of consumers seeking coffee, monuments, clothing or simply the 'pleasant' atmosphere of a specific urban district, and thus they also seem to show a dominance of middle class people. To return to the three aspects for complexity presented above, aspect one (the number of time-spaces produced) and two (the degree of overlapping time-spaces), seem to be well represented, perhaps even increasing, whereas aspect three (degree of variety and integrity between the territories) seems to be decreasing. The different urban districts are all quite complex in comparison with the homogenous Emporia, which appears to be striving for a 24/7 world of consumption, but they still seem to be in the midst of a slow homogenisation process where regularities on a super-territorial level seem to increase its hold. Delaney has described this kind of decrease of local autonomy and increase of "higher levels of government or other hierarchical organizations" (Delaney 2001:30) as a verticality of territories. Whatever we call it, it relates to the third aspect of a non-hierarchical territorialisation which is vital when it comes to time-space complexity (cf. Law and Mol 2002: $14 \mathrm{ff}$. ). In the following we will elaborate on two different ways in which this aspect seems to be slowly eradicated by analysing how the differences of opening hours between the four central retail areas can be 
seen as associated to certain spatial and temporal strategies. Here, some seem more inclined to spatial and others more towards temporal regulation.

Firstly, spatial homogenisation implies a synchronisation of the area's different spaces; the stores tend to exhibit similar rhythms and synchronised opening hours. This feature can be seen as related to the steepness of the curves of fig. 1 . The steeper the curve, the more stores open or close at the same time, contributing to a spatial territorialisation of the area by means of temporal access: all shops are open, or all shops are closed. This is often the case when chain stores or malls come to dominate a certain area, or with strong city associations working both with opening hours and with the synchronisation of different advertisement campaigns and events. In the present study, Angers and Lisbon seem quite synchronised in terms of opening and closing hours; this is particularly true in Angers, where the city association regulates opening hours. The city association of Malmö has deliberately tried to decrease the proportion of chain stores in Malmö city centre, but nevertheless, it works actively with different synchronisation strategies, especially in campaigns and events. Secondly, there is temporal homogenisation; that is, when every hour of the day or every day of the week assumes a similar character and the distinction between day and night, weekday or weekend is blurred. In the study at hand, Angers displays an easily distinguishable temporal differentiation - between Sundays and other days, and between midday and the rest of the day - whilst Chiado in Lisbon (perhaps unsurprisingly, as Lisbon is the largest city in this study) tends to have quite generous opening hours all through the day and the week. In terms of temporal homogenisation, the production of a new variety of distinction is discernible - one no longer induced by cosmic, cultural or seasonal varieties, but rather by a consumer logic. There is an ongoing temporal renewal; the setting up of events, pop-up stores and restaurants creates a necessary variety of the retailscape needed in order to keep consumers interested - but this variety is firmly juxtaposed against the steady and permanent rhythms of consumption. As opening hours in different cities extend in different fashions, the production of difference results from the orchestration of spatial events at certain times of the year instead, rendering these strategically produced events important in the production of distinctive time-spaces through-out the city and the year (Johansson and Kociatkiewicz 2011). 
Lefebvre has distinguished between linear and cyclical rhythms, claiming that they "exert a reciprocal action: they measure themselves against one another" (Lefebvre, 2004:8). The cyclical rhythms, he argues, are cosmic whilst the linear are social. Days and seasons continue changing in a circular way, but one might argue that the importance of cyclical rhythms diminished during the $20^{\text {th }}$ century as retail moved indoors and became increasingly dependent on artificial lighting, climate control, constant greenery, etc. The importance of cyclical rhythms related to cultural traditions; i.e. lunch breaks and days of rest, has also lessened. Angers has very regular opening hours, in the sense that most stores seem to open simultaneously. It thus represents a quite well conducted timescape with isorhythmic tendencies, combined with a sustained connection to cyclical and cultural rhythms.

\section{Time-space complexity and the City à la carte}

Examples of specialisation are discernible on a city- as well as a district level. In Angers and Porto, we saw how different streets were associated with different specialties, perhaps even evolving into what is sometimes referred to as branded streets (Wrigley and Lowe, 2002:195). Aliados in Porto, and the Chiado area of Lisbon can both be seen as complex spaces shared by people, regardless of their life-paths, cultures and ways of living, which offers a mixed pattern allowing for different temporalities. In the case of the central area of Lisbon, variety thus seems more significant than specialisation. However, if the centre in its entirety were taken into account, the specialisation of uses and temporalities would become more evident. Part of the Baixa, with its administrative and financial quarters and its declining retail, is deserted after 19.00 as well as on weekends, and the night spots in Bairro Alto and Cais do Sodré are full of movement until 3.00 in the morning; Chiado is situated in the middle of these two extremes. Chiado has its own very distinct time-space, and it differs from that of the adjacent neighbourhoods. In this sense, Chiado's distinctive timescape also plays a role in the territorialisation of Chiado as a retail district with an identity of its own. 
In the case of Malmö city centre, processes of territorialisation are discernible on at least two levels. First, there is the retailisation and pedestrianisation of the area; i.e. the development of a distinguishable and functionally specialised retail area within a more mixed urban centre, Secondly, there is an ongoing specialisation within this pedestrianised area, where Lilla Torg has been developed into a gastronomic area and Stortorget (the Main Square) is in the process of developing into a square for events. The northern part of the pedestrian precinct also has a focus on design, and a recent advertisement campaign (in 2014) even dubbed this part of the pedestrian precinct with the name 'Design City'.

Retail seems to be a more ambient part of society and urban life through internet shopping and ever-larger themed retail spaces. There seem to be more possibilities to consider, and consumers are presented with more choices than ever before (McMorrough 2001; Bishop and Williams 2012). One way to describe this is as an increased time-space compression. Harvey provides an example:

[T] he whole world's cuisine is now assembled in one place as neatly in almost exactly the same way that the world's geographical complexity is nightly reduced to a series of images on a static television screen. (Harvey, 1999:112)

A spatial strategy for achieving time-space compression is to keep a wide variety of consumable objects within every category, neatly packaged - or more accurately, produced - as a specific time-space. This can be described as the development of what Frank Lloyd Wright called the city à la carte (Fishman, 1990; Hajer and Reijndorp 2001). The expression, also recaptured by François Ascher (Ascher, 1995), is used to describe the home as the node of the metropolis, connected through different infrastructures. The city à la carte highlights the possibility of each individual to assemble a personal city. This is the city of consumption and mobility par excellence, as opposed to the city of those lacking the same conditions for mobility or who are for some other reason victims of spatial injustice as consumers (Soja, 2010).

We can observe the expansion of the consumer society and a development of hypermobile consumers where "the worker or flâneur citizen of the early $20^{\text {th }}$ century was progressively replaced by an explorer/consumer cluster with increasing loads" (Cochoy et al., 2015:2281), but where some lack the capacity to consume from the choice of articles and shops, or even 
to afford the costs of transport to the low-price standardised products outside the city centre. Mobile consumers move around, transporting personal goods on their shoulders in backpacks, which became fashionable during the 1980s, and commercial bags with logos in their hands (Cochoy et al., 2015, see also Brembeck et. al. 2015). They shop via smart phones and take only short breaks in cities increasingly designed for this new socio-technical assemblage of consumption, sharing the city with the omnipresent tourists and the impoverished - the numbers of which have increased dramatically with the recent refugee crises as well as economic crises and austerity trends. Inequalities in terms of mobilities have, in short, become a pressing issue. Today, as theming and branding are used as principles for urban development in lieu of zoning, we see a focus on the proliferation of options for some, rather than on the infrastructure of basic necessities for all (Nylund, 2014). The homogenisation and decrease in the time-space complexity of the investigated areas must thus be related to the scale of the urban landscape as a whole, and to some extent to a global scale of tourism as well. The city à la carte enables some to make the spatio-temporal choice of both where and when to visit. A variation of the protected environment of gated communities can thus become possible through 'neutral' or 'frictionless' mobility through a city fragmented (Barata-Salgueiro 1997) or splintered (Graham and Marvin, 2001, cf. Albrechts and Mandelbaum 2005) into a virtually endless mosaic of spatio-temporal pieces. One should note that the transition at hand is by no means one from a world of traditional, local habits to a globalised, flexible landscape (Shove, Trentmann and Wilk, 2009); the process is not one of borderless globalisation, but rather the multiplication of borders. (Mezzadra and Neilson, 2013:62). Time-space complexity is often desired in retail areas, but the proliferation of borders and territorial productions also seems to come with an increasing tendency of synchronisation and control. Even in relatively slow urban changes such as those in the areas of the present study, territorial production seems to be sorted into different hierarchies by means of a slow, but still observable spatial and temporal homogenisation. A central regime (such as a City association, a City chamber of commerce or local regulations) set the same rules for a whole number of different territories and synchronise them - and thus probably making the territorial agglomerate stronger in terms of impact, but also decreasing its complexity. This is echoed on the scale of the urban landscape where different areas and districts become 
points on a list or a 'menu', risking synchronisations on a new scale. This, in turn, might risk to bring with it an increase in consumption, transportation costs (both ecological and economical) and social inequalities, thus jeopardising the possibilities for a sustainable urban development.

\section{Concluding remarks}

In this article we have discussed the concept of time-space complexity, exemplified through a comparative study of retail opening hours in four European cities. Here, especially an increasingly hierarchical ordering of the territorial landscapes was identified. We then discussed how the theming or specialisation following in the wake of this spatio-temporal homogenisation and decreasing time-space complexity opens up for a city à la carte. The identified evolution thus augments the proliferating spatio-temporal borderscape of our cities, producing options for a consumerscape differentiated by moments of movement and rest, eating and shopping, daytime and nightlife, but also by differences of mobility and immobility, means and no means, legality and illegality, etc.

Our hope is that the present study can serve as a first pilot study into the increasingly curated time-spaces of our cities, and we would like to end with two concluding remarks. First of all, more studies need to be made concerning the structure of time-space production in our cities in order to bring more light on the complex processes and effects of spatio-temporal homogenisation (good or bad) and the seemingly on-going production of increasingly distinctive time-spaces. Not least, this concerns how territorialised time-spaces become produced on different scales and then aligned to each other in different ways (for example, how shops become aligned on a district level through the regulations of city associations). As discussed above, regardless of an increase in the sheer number of territories within an area, or in the fluidity of their borders, a stronger hierarchical control of these territories may result in either spatial or temporal homogenisation (or both). The study of opening hours does of course only bring a small part of the spatio-temporal landscapes to light, it needs to be complemented, and investigated in a more 
comprehensive manner in order to assess more structural effects, for example, how different processes of territorialisation relate to each other. Here, we think that the notion of time-space complexity can be used and further developed. Second of all (and on a more empirical note): if (or rather, where and when) retail has a tendency to dominate certain urban areas or districts, it might be important to set up a situation where some noncommercial activities are especially cared for, in hopes of understanding a more balanced relation between retail and other activities can contribute to more liveable city centres.

\section{References}

ALBRECHTS Louis and MANDELBAUM Seymour. Network Society, a new context for planning? London: Routledge. 2005.

ASCHER François. Métapolis: ou l'avenir dês villes. Odile Jacob: Paris. 1995

ATKINSON, Rowland. Domestication by cappuccino or a revenge on urban space? Control and empowerment in the management of public spaces. Urban Studies. 2003. 40.9. 1829-1843.

BALSAS, Carlos JL. City centre regeneration in the context of the 2001 European Capital of Culture in Porto, Portugal. Local economy. 2004. 19.4: 396-410.

BARATA-SALGUEIRO, Teresa. Lisboa, metrópole policêntrica e fragmentada. Finisterra. 1997. 32. 63: 179-190.

BELLONI, M. Carmen. Tempi delle citta: Italy's urban time plans and policies. Time \& Society. 1998. 7.2-3: 249263.

BISHOP, Peter and WILLIAMS, Lesley. The temporary city. London: Routledge. 2012.

BOULIN, Jean-Yves. Working on Sunday: Regulations, impacts and perceptions of the time use practices. In HENCKEL, Dietrich, THOMAIER, Susanne, KÖNECKE, Benjamin, ZEDDA, Roberto and STABILINI, Stefano. SpaceTime Design of the Public City. Springer Netherlands. 2013: 21-35.

BOYLAUD, Olivier and NICOLETTI, Giuseppe. Regulatory reform in retail distribution. OECD Economic studies, 2001.1: 253-274.

BREMBECK, Helene, HANSSON, Niklas and VAYRE, Jean-Sébastien. Life Phases, Mobility and Consumption: An Ethnography of Shopping Routes. Farnham: Ashgate. 2015.

BRIGHENTI, Andrea Mubi. On territorology: Towards a general science of territory. Theory, culture \& society. 2010, 27.1: 52-72.

BRIGHENTI, Andrea Mubi. Mobilizing territories, territorializing mobilities. Sociologica, 2014, 8.1: 0-0. doi: $10.2383 / 77043$.

BRIGHENTI, Andrea Mubi and KÄRRHOLM, Mattias (2016). Three presents: On the multi-temporality of territorial production and the gift from John Soane. Time \& Society, Publ-ahead-of-print. 0961463X16678254.

CIVILDEPARTEMENTET. Affärstiderna. Betänkande av 1989 års affärstidsutredning. Stockholm: Civildepartementet. 1991. 
COCHOY, Franck; HAGBERG, Johan; CANU, Roland. The forgotten role of pedestrian transportation in urban life: Insights from a visual comparative archaeology (Gothenburg and Toulouse, 1875-2011). Urban Studies. 2015. 52.12: 2267-2286.

CRANG, Mike. Temporalised space and motion. In MAY, John and THRIFT, Nigel. Timespace: Geographies of Temporality. London: Routledge. 2001: 187-207.

CRONIN, Anne M. Advertising and the metabolism of the city: urban space, commodity rhythms. Environment and Planning D: Society and Space. 2006. 24.4: 615-632.

DELANEY, David. Territory: a short introduction. Oxford: Blackwell. 2001.

DELFOUR, Christine and DOMMERGUES, Pierre. Time-related policies in France, in DELFOUR, Christine and DOMMERGUES, Pierre, Concillation Policies in France, Paris: Afet. 2003.

EDENSOR, Tim. Geographies of Rhythm: Nature, Place, Mobilities and Bodies. Farnham: Ashgate, 2010.

FERNANDES, José Rio. Area-based initiatives and urban dynamics. The case of the Porto city centre. Urban Research \& Practice. 2011. 4.3: 285-307.

FERNANDES, Jose Rio and CHAMUSCA, Pedro. Urban policies, planning and retail resilience. Cities. 2014. 36: 170-177.

FERNANDES, Jose Rio, CHAMUSCA, Pedro and FERNANDES, I. Aliados Avenue and Centre of Porto Porto Vivo, SRU. 2013.

FISHMAN Robert. America's New City, The Megalopolis Unbound. The Wilson Quarterly, 1990.14.1: 24-55.

GORTER, Cees, NIJKAMP, Pete, and KLAMER, Pim. The attraction force of out-of-town shopping malls: a case study on run-fun shopping in the Netherlands. Tijdschrift voor economische en sociale geografie, 2003. 94.2: 219-229.

GRADUS, Raymond. The economic effects of extending shop opening hours. Journal of Economics. 1996. 64.3: 247-263.

GRAHAM, Stephen and MARVIN, Simon. Splintering urbanism: networked infrastructures, technological mobilities and the urban condition. London: Routledge. 2001.

HAJER, Maarten and REIJNDORP, Arnold. In search of new public domain. Rotterdam: NAi. 2001.

HARVEY, David. Time-space compression and the postmodern condition. Modernity: Critical Concepts. 1999. 4: 98-118.

HENCKEL, Dietrich, THOMAIER, Susanne, KÖNECKE, Benjamin, ZEDDA, Roberto and STABILINI, Stefano. Spacetime design of the public city. New York: Springer. 2013.

JOHANSSON, Marjana; KOCIATKIEWICZ, Jerzy. City festivals: creativity and control in staged urban experiences. European Urban and Regional Studies. 2011. 18.4: 392-405.

KÄRRHOLM, Mattias. The materiality of territorial production: a conceptual discussion of territoriality, materiality, and the everyday life of public space. Space and culture. 2007. 10.4: 437-453.

KÄRRHOLM, Mattias. To the rhythm of shopping-on synchronisation in urban landscapes of consumption. Social \& Cultural Geography. 2009. 10.4: 421-440.

KÄRRHOLM, Mattias. The temporality of territorial production-the case of Stortorget, Malmö. Social \& Cultural Geography. 2017. 18.5: 683-705.

KLINGMANN, Anna. Brandscapes: Architecture in the experience economy. MIT Press. 2007.

LATOUR, Bruno. Reassembling the social: An introduction to actor-network-theory. Oxford: Oxford University Press. 2005.

MOL, Annemarie and LAW, John. (Eds.). Complexities. Durham: Duke University Press. 2002.

LEFEBVRE, Henri. Rhythmanalysis: Space, time and everyday life. London \& New York: Continuum. 2004. 
LOW, Setha M. The erosion of public space and the public realm: paranoia, surveillance and privatization in New York City. City \& Society. 2006. 18.1: 43-49.

LYNCH, Kevin. What time is this place? Cambridge MA: The MIT Press. 1972.

MAREGGI, Marco. Innovation in urban policy: the experience of Italian urban time policies. Planning Theory \& Practice. 2002. 3.2: 173-194.

MAREGGI, Marco. Urban rhythms in the contemporary city. In HENCKEL, Dietrich, THOMAIER, Susanne, KÖNECKE, Benjamin, ZEDDA, Roberto and STABILINI, Stefano. Space-Time Design of the Public City. Dordrecht: Springer, 2013: 3-20.

MASSEY, Doreen. For space. Sage: London. 2005.

MAY, John and THRIFT, Nigel. Introduction. In MAY, John and THRIFT, Nigel. Timespace: Geographies of Temporality. London: Routledge. 2001: 1-46.

MCMORROUGH, John. City of shopping. In Harvard Design School Guide to Shopping. Köln: Taschen. 2001: 192-203.

MERRIMAN, Peter. Human geography without time-space. Transactions of the Institute of British Geographers. 2012, 37.1: 13-27.

MEZZADRA, Sandro; NEILSON, Brett. Border as Method, or, the Multiplication of Labor. Durham: Duke University Press. 2013.

MILES, Steven; MILES, Malcolm. Consuming cities. New York: Palgrave Macmillan. 2004.

MÜCKENBERGER, Ulrich. Local time policies in Europe. Time \& Society. 2011, 20.2: 241-273.

MULÍČEK, Ondřej, OSMAN, Robert and SEIDENGLANZ, Daniel. Urban rhythms: A chronotopic approach to urban timespace. Time \& Society. 2015. 24.3: 304-325.

NEUHAUS, Fabian. Studies in Temporal Urbanism. Berlin: Springer. 2011

NYLUND, Katarina. Conceptions of justice in the planning of the new urban landscape-Recent changes in the comprehensive planning discourse in Malmö, Sweden. Planning Theory \& Practice, 2014, 15.1: 41-61.

PAIVA, Daniel, CACHINO, Herculano, \& BARATA-SALGUEIRO, Teresa. The pace of life and temporal resources in a neighborhood of an edge city. Time \& Society. 2017. 26.1: 28-51.

PARKES, Don and THRIFT, Nigel J. Times, spaces, and places: A chronogeographic perspective. New York: Wiley. 1980.

RAVENSCROFT, Neil. The vitality and viability of town centres. Urban Studies, 2000, 37.13: 2533-2549.

SCHATZKI, Theodore R. The timespace of human activity: On performance, society, and history as indeterminate teleological events. Lanham: Lexington Books. 2010.

SHOVE, Elizabeth. Everyday practice and the production and consumption of time. In SHOVE, Elisabeth, TRENTMANN; Frank and WILK, Richard. Time, consumption and everyday life: Practice, materiality and culture. London: Berg. 2009: 17-34.

SIMPSON, Paul. Apprehending everyday rhythms: rhythmanalysis, time-lapse photography, and the spacetimes of street performance. cultural geographies. 2012. 19.4: 423-445.

SOJA, Edward W. Seeking spatial justice. Minneapolis: University of Minnesota Press. 2010.

SOUMAGNE, Jean. Temps et usages de l'espace. Rennes: Presses Universitaires de Rennes. 2015.

VAN SCHAIK, Joost. Timespace matters-Exploring the gap between knowing about activity patterns of people and knowing how to design and plan urban areas and regions. TU Delft, Delft University of Technology. 2011.

WARNABY, Gary. Synchronising retail and space: using urban squares for competitive place differentiation. Consumption Markets \& Culture. 2013. 16.1: 25-44. 
WRIGLEY, Neil. 'Food deserts' in British cities: policy context and research priorities. Urban Studies. 2002. 39.11: 2029-2040.

WRIGLEY, Neil and LOWE, Michelle. Reading Retail: A Geographical Perspective on Retailing and Consumption Spaces. London: Arnold. 2002.

WUNDERLICH, Filipa Matos. Place-temporality and urban place-rhythms in urban analysis and design: An aesthetic akin to music. Journal of Urban Design. 2013. 18.3: 383-408.

WUNDERLICH, Filipa. Place-temporality and rhythmicity: a new aesthetic and methodological foundation for urban design theory and practice.In CARMONA, Matthew. Explorations in urban design: An urban design research primer. 2014: 59-76. 